\title{
Different approaches to the relationship of life \& death (review of articles)
}

\section{Martin Gluchman ${ }^{1}$}

\author{
The aim of health care \\ "is not to add years to life, but life to years" \\ (Campbell et al., 1997, p. 138).
}

\begin{abstract}
The paper presents different approaches to the relationship of life and death among selected authors as a review of their articles within the last volume of the Ethics \& Bioethics (in Central Europe) journal. The resource of the review is an article by Peter Singer The challenge of brain death for the sanctity of life ethics. Firstly, I try to analyze the issue when death occurs and when we can talk about death as a phenomenon that each and every living human being must come to terms within the course of their lives. Ethics of social consequences is used to analyze different approaches and states a conclusion defending the principles of humanity and human dignity within the scope of this ethical theory applied to various problem cases. I strive to support the question of the quality of life through the paternalistic approach of physicians influenced by their humane and dignified understanding of their relationship towards the patients. Ethics of social consequences offers many solutions to the discussed issues throughout the reviewed articles.
\end{abstract}

Keywords: death, humanity, dignity, ethics of social consequences, quality of life

\section{Introduction}

The main idea of this paper is to present death in relationship to life within my scope of perspective directly confronted, reviewed and analyzed with different viewpoints of those authors found in the last issue of the journal Ethics \& Bioethics (in Central Europe). The methodological scope I used is the theory of ethics of social consequences compared to other views within the field of bioethics and medical ethics. I reviewed and compared several positions and standpoints of authors contributing to and analyzing Peter Singer's article on the challenge of brain death understood within different perspectives and methodological approaches. Those standpoints include those of Piotr Grzegorz Nowak (stating the role of the physician in relationship to the patient and explaining death in his understanding), Ireneusz Ziemiński (time and processuality of declaring death), Mariusz Wojewoda (the value of death) and Katarína Komenská (quality of life and dignified death). I refer, as well, to Singer himself who compared his development of ideas within the topic throughout history. Analyzing the papers and confronting them with my position within ethics of social consequences brings about other interesting questions to the problem issues I tried to answer and defend my position towards.

\section{When does death occur?}

As death is ambiguous, we would be able to talk about death as a human, or inhuman, process within ethics of social consequences. Death would be the manifestation of humanity in the case of escaping suffering when terrible pain is born by a terminally ill patient. On the contrary, death is the manifestation of inhumanity when killing as a crime in its proper meaning happens. When searching for the answer to the question "What is death?", I found several types of answers or cases bringing death. The death of a human being can be pronounced at the time death of the brain stem occurs. In such a case, the physician can diagnose brain death if certain criteria are fulfilled, according to which we must conclude the coma is not caused by any other reasons

\footnotetext{
${ }^{1}$ College of the Marshall Islands (Republic of the Marshall Islands); email: martingluchman@yahoo.com
} 
(Herring, 2006, p. 409). Singer defines brain death as the death of the human organism using the President's Commission's definition because, without brain function, the body is no longer an integrated whole, but just a collection of cells and organs. Singer adds that brain death is defined as the irreversible cessation of all brain functions (Singer, 2018, p. 155). We must definitely complete this idea by thinking in a way that, when talking about the death of our cells, as Komenská states in her paper, we are no different from all of the other organisms on earth condemned to die as a condition of birth. [...] we normally think of death in the terms of death of the person - the integrated whole composed of personality, will, memory, passion, and the hundreds of other things that make each of us unique $[\ldots]$ and the loss of "personhood" $[\ldots]$ is increasingly viewed as one of the most important aspects of human death" (Clark, 1996, pp. x-xi; Komenská, 2018, p. 204). Additionally, Alan Shewmon writes, the diagnosis of brain death is nearly always "a self-fulfilling prophecy" as it is followed by organ harvesting or the discontinuation of support. Occasionally, however, a family will insist on support being maintained even after a diagnosis of brain death (Shewmon, 1998, p. 1543; Singer, 2018, p. 156). Death can occur when respiration has (been) stopped at the moment the patient's heart has stopped circulating blood and respiration has consequently stopped. However, medical development made this definition even more problematic. Presently, it is clear the cessation of the heart does not bring the cessation of brain activity (Mason, 2012, p. 97; McCall Smith, 1997, p. 23; Laurie, 1997, p. 120). The argument against such an opinion is when through the ventilation of the body we stop the physician's activity terminating the life of patient using a respiratory unit or electric stimulation in case there was a heart attack that can possibly save the patient being close to death.

Nowak states that, within everyday life, determining whether someone is alive or not is of great importance for us. The attitudes and behaviors which we present towards the living differ radically from those which are manifested towards the deceased (Nowak, 2018, p. 169). I have to ask the question "Why?" Why does it differ? Is it only within our common sense understanding of life or are we, humans, only compassionate to those in need or danger? I believe we should treat everybody equally, no matter the health conditions, mental state, etc. As per the criteria of ethics of social consequences, until that time we meet the criteria of sentient human beings, ethically, and even biologically, we are still human beings possessing the capacities to live our lives. On the other hand, according to ethics of social consequences, we need to question positive social consequences and bring them to terms in order to assess the lives of human beings themselves or the benefits that human beings in the stake are bringing to society.

As Nowak states, one of the main reasons for this is the widespread belief that only the living might be helped or harmed (Nowak, 2018, p. 169). In my opinion, that is highly disputable. Yes, I definitely agree that the attitudes and behaviors we present differ radically, but I think the other way. Who has made such a decision or based on what social issues can we say that? I think, predominantly, those in danger or towards the end of their lives are mostly compassionately helped as their family relatives are afraid of their lives and are actually trying to save them (sometimes for the sake of their own feelings, their inability to relieve their engagement in the case of their family member and being too involved and afraid of losing somebody close, not considering the health conditions and the state of, e.g., a terminally ill patient - not mentioning the wishes and desires of said terminally ill patient, the moral agent meeting the criteria for moral agency). However, Nowak claims, it is clear that the word "life" appears in this context in an ethical sense, not in a biological one, because biological life itself may have nothing to do with experiencing harms or benefits (Lizza, 2018, p. 13; Veatch, 2015, p. 299; Nowak, 2018, p. 169). 
Based on the ethics of social consequences, we should care about positive social consequences throughout the entire life of human beings. No matter what is the moral status of the agent, we should rather look at both principles of dignity and humanity of the life of an individual. Vitalism, similarly to the religious point of view, holds the view that human life has an absolute value. Therefore, we are never obliged to kill another human being. Physicians should undertake all the possible precautions to keep people alive. That is the reason the physician is not allowed to commit acts harming the patient and causing death or to fail to execute the proper precautions in an effort to keep a person alive. That is in direct agreement with the words of Pope John Paul II in Evangelium Vitae: "As far as the right to life is concerned, every innocent human being is absolutely equal to all others..." For those who take this view, if brain dead human beings can be kept alive for many years without the use of scarce medical resources, the distinction between "ordinary" and "extraordinary" or between "proportionate" and "disproportionate" means of care cannot be used to justify withdrawing medical support from them (Singer, 2018, p. 163). The concept of the sanctity of life insists human life is an important essential good. This movement holds the view man ought not to be killed willingly. This approach is quite close to the Christian understanding of the relationship between life and death and its general standpoint towards euthanasia. However, advocates of the quality of life conclude life should be assessed upon its quality and make a further decision regarding life itself consequently. It is about the essential approach of quality of life which is responsible for achieving the value of a patient's life. Personally, I believe artificially keeping a man alive is the manifestation of inhumanity, in spite of the social death of the human being itself.

Similarly, Singer in his Challenge of brain death for the sanctity of life ethic states the existence, over the past three or four decades, of the definition of death in terms of brain death has, quite literally, made it possible for Christians to get away with what would, under the earlier traditional definition of death, have been murder - and without abandoning their support for the sanctity of all human life. Moreover, if brain death is not the death of the human organism, it is hard to see how defenders of the equal value of all human life can support the removal of ventilators from brain-dead patients with beating hearts. Roman Catholic teaching holds that extraordinary treatment is not obligatory when it imposes a disproportionate burden on the patient or others disproportionate, that is, in terms of the benefits gained. This doctrine allows Christians to discontinue extraordinary means of life-support that are burdensome to a patient or demand scarce medical resources, and the burden on the patient or the use of resources is disproportionate to the benefit that will be achieved. This may be the case when the patient is suffering and will, in any case, live for only a short time, or when the medical resources could save other patients who will live much longer (Singer, 2018, p. 163). In terms of ethics of social consequences, I would rather oppose such a rigid standpoint of the will to keep a patient alive at any cost, just not to damage the sanctity of life and the common understanding of being alive. We should rather look at the quality of life from the perspective of the principles of humanity and dignity, in which case the patient (up to the conditions he/she can be considered as a moral agent fulfilling certain conditions) must be the one to make that decision, fully supported by his/her family members and other relatives. Analyzing the moral judgments, quality of life should be the primary condition in order not to suffer before questioning whether to extend the patient's life or discontinue treatment.

Analyzing Vasil Gluchman's opinion on our effort to save and maintain human life, we must be careful not to return to inhumanity, thus the effort to preserve this life by all means. If human life doesn't resemble the content of humanity in its minimal extent, only its biological survival of a human body, then the protection of the care of such human life is not a moral value because such 
life exists only in its natural-biological form. That is the reason we need to approach it in the same way. Animals do not prolong the life of their relatives and let them die. We could possibly say and apply it within the human kind, as a natural-biological form of showing respect to humanity. However, it doesn't mean we let a man die without any care because it deserves at least minimal care as a form of human life. We don't provide other medical care limiting the natural process of the existence of the organism, thus prolonging its survival. It is absolutely not inhuman or immoral to let a human life living at the level of the biological survival of the human organism die (Gluchman, 2005, p. 617). Therefore, it is significant to understand the broader extent of the term humanity and to not reduce humanity to the protection of life only or keeping any form of life blindly by all means.

Death is awful and generally painful. To defend and pretend it is not and request from physicians a perfect painless death is a supreme refutation of the fact of death (Herring, 2006, p. 449). I would like to support my ideas opposing this belief with a very apt comparison as Nowak compares the scientific concept of death ${ }^{2}$ with the meaning of "death" which occurs in ordinary language. He realizes that they are not congruent. This might be easily discernible in the case of the sentence "His death was a great tragedy" which would be incomprehensible if we meant the biological meaning of "death" in this case. Death is commonly seen as bad for the person whose life ends (particularly if someone young dies who would otherwise have had many years of healthy life left, see for example McMahan, 2012, pp. 95-145; Nagel, 1970; Nowak, 2018, p. 169). Based on the ethics of social consequences and my position towards death, I have to argue against a statement like "Death is commonly seen as bad". Why would it be bad even for the person whose life ends? If I am terminally ill in terrible pain, I would love the relief and consider death as a positive outcome. In such a case I am trying to find my way out of pain and to escape the torture it causes and is related to my unrelenting suffering. Yet it is rather unclear why for any kind of being that the mere fact that it ceases to be a system which is capable of resisting entropy might be bad. Above of all, Nowak comes to the conclusion that the definition proposed by Nair-Collins also does not explain why death might provide the loved ones with a reason to start mourning, although it widely believed that it really does (Nowak, 2018, p. 169).

In my opinion, I highly believe that the term dignified death is only a socially constructed ideal which we strive to cover and hide the reality and inevitability of death which, sooner or later, happens. However, we still can "simplify" the process of a patient's dying; make it easier and more pleasant. I think it all is only about helping the patient to mitigate his/her suffering, although to a minimal extent. Consequently, it could mean a lot for the patient in his/her painful state, up to the stage we would realize that death itself is a dignified fact we can easily face as we understand the core basis of the principles of humanity and human dignity of life. We must consider the humanity of this process as well as the positive social consequences which might come about because of our assistance. Therefore, I think we definitely need to keep the principles of ethics of social consequences in mind before we commit any possible deeds in order to help or do no harm within the reflection or our role in relation to dying or terminally ill patients.

\footnotetext{
2 "Death" in its biological meaning might be defined as follows (...) [it] is the irreversible cessation of the organismic capacity to maintain homeostasis of the extracellular fluid and thereby resist entropy. Extending the homeostenosis concept of aging, death is the limit beyond which homeostasis cannot be restored, when physiologic reserves are spent (...). It is a thermodynamic point of no return, a state-discontinuous point beyond which entropy and disintegration take over" (Nair-Collins, 2018, p. 33).
} 
In contrast to these statements, Nowak, quoting Michael Nair-Collins, points out that the view which admits organ donation associated with killing living humans has a major drawback: it is associated with a misleading concept of death. Nowak argues that the right concept of death associates the end of human life with the irreversible loss of consciousness and also defends such a view against the latest criticism developed by Nair-Collins (2017) (Nowak, 2018, p. 167). But my question is "What is the right concept of death?" I believe there is no right or wrong explanation and understanding of what death is or the question when does one come to terms with death within the scope of the dignity of human life itself. On the contrary, it is related to the moral values of those human beings who were respected during their life and what moral good they brought to society during their life at all based on their deeds, thus, generally speaking, positive social consequences.

But Nowak builds his opinion on the basis of such a position that we can understand why death can be considered as bad for humans (because when humans lose their moral status, at the same time they lose the prospect of further good which might be available for them if they did not die, see McMahan, 2012, pp. 95-145; Nagel, 1970), and why death gives reasons for mourning (Nowak, 2018, p. 170). On the contrary, I think that in spite of humans losing their moral status, I do not agree they necessarily lose their hope and prospect for achieving further good. I am aware of the criteria and determinants considering the moral status of the moral agent. But it does not predominantly mean only a bad presumption towards the future of such individuals. I think there still is a chance and hope for good in terms of the question of euthanasia in the case of terminally ill patients striving to end their fulfilled and satisfied lives happily according to their wishes, even though not morally acceptable within society in general considering good as something bringing positive social consequences only to them or society at all. We must deal with such cases individually and consider them from a higher moral perspective.

\section{Quality of life of a dying human being}

The awareness of mortality in the context of terminal illness has a high level of perception among humans. This inevitable and indescribable relationship between the fact of mortality and the thoughts of "good living" in the case of palliative care supports the significance of the equality of life of patients and their families. When it is clear that life is coming to an end and we cannot compensate it with our deeds in the future, the patients and all those around them are focusing on achieving the ideal of the best possible quality of remaining life. However, it is more important to ask the question "What do we think by improving the quality of life?"3

Within the theory of humans as beings with the ability of self-reflection and acting, we can find the position related to the quality of life. The theory presents the significance of the quality of life of human beings rather in terms of the standards of individual well-being than in terms of social moral value (Cohen, 1983, p. 114). Life, as defined by ethics of social consequences, as a moral value must be protected and supported as long as it is at least about life in a minimal extent related to the quality criteria of human life. It is fully related to humanity as a moral attribute as a solely human expression of behavior and acting. Another situation arises in the case of human life not meeting the minimum quality criteria related to a human life (either from its beginning or in the process of its existence), as Katarína Komenská and Ján Kalajtzidis mentioned in their papers (for

\footnotetext{
${ }^{3}$ The term of "quality of life" became a part of literacy and is commonly used even in a health care as well as a daily life (Randall \& Downie, 2006, p. 27). "The quality" can simply mean the attribute, value, characteristics or nature of somebody or something. In this sense, the term "quality" is purely descriptive, describing some fact or identifiable situation, therefore it is neutral in its value.
} 
further details see Komenská, 2018, p. 204; Kalajtzidis, 2018, p. 213; Švaňa, 2016; Klembarová, 2015; Lešková Blahová, 2010) and there is no hope for change in the future, meaning this form of human life cannot exceed the level of the biological existence of an organism. In such a case, we need to approach this form of life as a natural-biological value and possibly let it die. Therefore, ethics of social consequences holds the view not to prolong the suffering of a human being as well as its relatives (Gluchman, 2005, p. 617).

We face a dilemma of undefinable nature of the best interests, lack of interest and the term where there is no absolute claim for attempting to prolong life by all means. Singer, defending the non-voluntary euthanasia of severely disabled infants, wrote:

"Arguments presume the life is better with no disability than with it and it is not the form of presumption dominant in the lives of disabled humans. It is not difficult to find a mistake in this argument. It proves the men suffering from various disabilities willing to live their lives fully should be helped as much as we can. It is different to argue if we are in a position we can choose whether our next child begins its life with or without a disability. It is only prejudice or subjectivity leading us to choose the child without a disability. If the magical medicine helping the disabled people on a wheelchair had been offered to use their legs fully without any side effects, how many of them would have refused it reasoning the life without a disability is not worse than living with a disability? When searching for the medical treatment to overcome and eliminate disability, the disabled ones possibly show the advantage of the life without a disability is not only a pure prejudice" (Singer, 1993, p. 395).

Singer is structuring his thoughts in the same direction even after a certain period of time as he develops his moral permission in the case of organ retrieval towards organ donation in the case of terminally ill patients defending his point of view claiming "[the] meaning of terms such as "life" or "death" in the context of human beings is not just biological - [C]onscious beings die when they irreversibly lose consciousness". Exactly this kind of "person's" death might make organ retrieval from the consenting donor morally permissible (Singer, 2018, p. 164).

From the point of view of ethics of social consequences, every single human life human deserves dignified treatment for the reason of being a living human. The question of fulfilling the qualitative criteria of human life itself of disabled human individuals is a controversial issue. As I stated my position analyzing the case mentioned above, based on these qualitative criteria, we would look at the prospective growth and development of the individuality of man, either he/she is or will be able to lead a valuable and dignified life in the future. A mentally disabled individual deserves respect for his/her life, as being a human being. But man cannot contribute to society solely by his/her actions and behavior, therefore, life cannot be considered (depending on mental disability) as dignified (if dignified at all), or as high-quality as the life of healthy individuals. Hence, a seriously disabled individual has the right to free will or the decision to end life. If men are so seriously disabled as to be free of their rights, their family relatives have the right to allow euthanasia considering there is no further chance to improve their health conditions and their lives are undignified. Other criteria for their decision-making to terminate the life of an individual are undignified, even inhuman conditions incompatible with good and quality life. The decision to terminate the life of a seriously disabled man (executed by himself or a legal representative) must be approved and medically treated by the physician in charge of the patient's conditions, who can consider the prospective health condition of the particular patient.

Above all, Singer is answering my question Why is it beneficial and profitable to help the patient to die or assist him/her with suicide and bring him/her to death? by claiming "We would be able to relieve the burden on families, hospitals and those in need of hospital beds, not only 
when the patient's brain has wholly ceased to function, but also when the patient's higher brain has irreversibly ceased to function. We would be able to do this without having had to finesse the definition of death in order to achieve our objective" (Singer, 2018, p. 163).

However, it is crucial to distinguish the quality of life from the value of life. The quality of life can be used to increase the value of respect towards the others as a part of a moral society (Small, Froggatt \& Downs, 2007, p. 147). On the other hand, Cohen proves a study of the quality of life striving to possess a larger or smaller value depending on the circumstances. The danger of being involved in the discussion on the quality of life is a misleading rationalization because "the idea of the quality of life is changing to the opinion on the value of human life. (The incorrect line of reasoning follows: "The life of very poor quality is not worthy of living. If the life had not been worth of living, it would not have had any value") (Jennings, 2004, p. 198). Wojewoda thinks the relationship to death is a test of our humanity. When referring to one's own and the mortality of others, we can check to what extent we are on the side of those values whose implementation requires from us personal courage, such as honesty, justice, openness, or the ability to work uncompromisingly, in situations posing a threat to other people's life or health (Wojewoda, 2018, p. 225).

The issue we deal with is a typical dilemma in most of the questions, whether euthanasia or not. The paternalistic approach of physicians supported by their experiences and scientific knowledge proves that the patient has no chance for a better life, indirectly claiming there is very low quality of life in such a case (Gluchman, 2014b, p. 76). Their paternalistic approach is opposed by parents, greatly influenced by their emotions and relationship to a child. Otherwise, ethics of social consequences primarily respects and attributes the value to the life of a child, but secondarily, fulfills the qualitative criteria of life in a natural-biological way only. From the moral point of view, it even doesn't aspire for the status of a potential moral agent capable of independent existence, decision-making, acting, and behavior. The theory agrees with the opinion of physicians to enable a patient to die. What defines the quality of life depends on the position we see a particular life in. Designing the measure of the value of quality of life can clearly presuppose the focus on the quality to be human, able to argue that some lives do not possess quality. In case it is an issue, we can consider the possibility to terminate life, but it depends on particular circumstances.

Regarding the paternalistic approach of physicians, I agree with Nowak as he states "physicians are not biologists or scientists engaged solely in describing natural phenomena or constructing scientific theories which might investigate whether they are witnessing biological life or death" (Nowak, 2018, p. 169). Afterward, Nowak continues defending his standpoint that "Physicians are first and foremost therapists, and their main task is to promote the wellbeing of a patient in accordance with medical knowledge. For this reason, physicians should be interested in whether the patient is alive or has died in the fundamental meaning of this world - that is in the ethical sense" (Nowak, 2018, p. 169). I cannot express my agreement with this statement fully, because that is definitely not the ethical sense of being a physician. Yes, I agree physicians primarily have to care whether the patient is alive or has died. But on the other hand, I would rather call it a biological function and the purpose of the role of a physician as his/her occupation. But, additionally, I also understand the ethical role within his/her deeper involvement into a behavioral issue, namely the mental and emotional state of a patient, the physician-patient relationship of understanding not only the "biological state" of a patient but even the patient's moral status within the society. That means how well a patient is dealing with the information or knowledge the physician shared with him/her so far. 
Ziemiński sees the obstacle in defining and declaring death in its processuality which makes it harder to point to a specific event which turns a living person into a dead one. While it is obvious that if all of somebody's cells died then they too are dead, but it would also be a mistake to wait until the last cell dies in order to declare somebody dead. Searching for a specific event that makes the process of dying irreversible is equally problematic because it is not clear that such an event exists (Ziemiński, 2018, p. 191). Yes, of course, it would be a mistake. Generally, there is no need to wait until the "right" moment, until the last body cell dies because there is an option when a patient, or a physician, within the approval of an informed consent can perform/proceed with the assisted suicide or just inform the patient on the possibilities within their health conditions and future treatment or the cessation of the nutrition of the patient's dying body. Another condition then comes into the equation and we have to question whether the moral subject is morally competent to make such vital decisions.

A physician deciding whether to continue treatment or let the patient die is a similar situation, each decision like this is based not only on medical data but also on moral beliefs. This suggests that the pronouncement of death can be as arbitrary ${ }^{4}$ as declaring someone to be an adult because it is affected by various factors (including an understanding of the value of life) (Ziemiński, 2018, p. 191). I would add an additional condition to the physician's decision-making process regarding the future treatment of a patient, that is equally as vital as Ziemiński's proposed moral beliefs that in some cases could easily be not enough - last but not least we have to think of the choice and preference of patient, as "a stakeholder" in his/her own life. The patient is the one who needs to be asked regarding such important and vital questions considering his/her life. It is all about the patient's autonomy and his/her freedom of choice.

For the sake of all the practical decisions that are made in everyday life, it is of great importance whether they concern the living or the dead. Facing someone's premature death in Nowak's opinion (Nowak, 2018, p. 175), he thinks we are overwhelmed with grief, and death is seen as bad for the person who has died. Based on my knowledge of the issue, there is no distinction between "a premature death" and "a regular death" from the perspective of ethics of social consequences. Death is a death with no further positive consequences but the relief, the end of the harm the patient suffered from, his/her remaining moral status as a former moral agent's status of being a capable human moral being. On the other hand, Nowak concludes his string of thoughts emphasizing the dead is not cared for by physicians, unlike the living. He believes that the dead cannot be helped anyhow (only humans in an atemporal sense might be helped if we pursue their will, but we cannot help the dead, that is we cannot help the body which presently constitutes the remains of a once living person) (Nowak, 2018, p. 175). I would like to oppose Nowak's opinion that the dead cannot be helped anyhow. We have to think in terms of the principles of dignity and humanity as even the dead have (eventually $h a d$ ) the moral right to die in a dignified way. Physicians have the obligation to treat their patients until the last moment of their lives and provide the best care possible. Even in the case of terminally ill patients, as there is no hope or way to save the life of the patient (either brain dead or in a vegetative state), the Hippocratic Oath drives them to do their best to provide all their knowledge and skills towards ensuring their dignified deaths.

A dignified death is something we, as the representatives of the human race, are entitled to within our profound humanity and are determined to decision-making depending on our beliefs, judgments, and understanding of our needs towards the end of our lives. Komenská presents a possible understanding of death with dignity in the ethics of social consequences. Patients, who

\footnotetext{
${ }^{4}$ It is definitely not as arbitrary as declaring to be an adult as there are many other conditions the physician cannot miss in order to pronounce someone's life to be over (Kalajtzidis, 2012).
} 
fulfill the criteria of moral agency (Kalajtzidis, 2012), might relate death to the question of quality of life. In these cases, moral agents are able to understand their life with their purpose and they are able to set their own vital goals. The wishes and goals of moral agents should be of the highest importance in making any decision regarding their death. Therefore, she comes to the conclusion that dying with dignity might be for them an eligible answer to ethical dilemmas, mostly if they cannot fulfill their goals and if they consider their life to be irreversibly bad and full of suffering (Komenská, 2018, pp. 205-206).

Similarly, it is applied in my book Problém humánnosti a l'udskej dôstojnosti v bioetike [The Problem of Humanity and Human Dignity in Bioethics] where I differentiate assisted suicide from euthanasia by the role of the physician in conducting particular actions, or the patients' wishes and requests. In assisting a patient's suicide, the physician is only a passive observer joining the process by providing professional advice, means of death and supervision. Whereas, in the case of euthanasia, the physician actively helps the moral agent to commit the act of killing for the sake of achieving a dignified death or the death without humiliation the patient has chosen for himself/herself as they did not see any escape from a deadly terminal illness. Freedom in decision making plays a very important role in both cases, as well as the present health condition of the patient and his mental state necessarily influencing the process of decision-making. In both cases, the motivation of individual decisions is dignity to the end of their lives and the vision of relief, certain assistance in their present painful suffering (Gluchman, 2014a, pp. 62-63; Gluchman, 2013).

\section{Conclusion}

To conclude, I definitely have to declare that ethics of social consequences must be related to its primary principles, goals, and values of humanity and human dignity within the crucial role of the decision-making related to such an important dilemma as death itself. As Kalajtzidis states, both crucial values are understood in connection to the protection, support and development of human life meeting the criteria of the theory towards the questions of life and death (Kalajtzidis, 2018, p. 216). No matter what bioethical dilemma we deal with, either harvesting the organs of dying/already dead people or any case of euthanasia, we definitely need to bear in mind the value of human life itself not just at the beginning but even at the very end, in its finale. We have to think of life coming closer towards death generally, considering its full length, not only the final moments when the suffering of a patient and the mourning of compassionate family members are extensive and can easily influence the decision-making of an individual. There are interesting approaches defending their own positions presented in the last issue of Ethics \& Bioethics (in Central Europe), differing from the rigid religious standpoint not allowing any non-traditional solutions up to more benevolent offerings of a progressive way to deal with these issues. In such cases, we must be egoists and individuals in order to provide the best possible solution to be done due to our good will and knowledge/awareness. We are the ones responsible for our lives, parts of the body and deeds throughout our entire lives until the very end. Therefore, applying the principles of ethics of social consequences, we must protect, control and support our compassion with suffering ones and our need to help, protect and support life itself until the moment life is morally valuable. Consequently, the role and the purpose of the physician within the physicianpatient relationship is to guide a patient through the process of death until the very end. Promote the knowledge, provide efficient support and flourish the principles of humanity and human dignity in case of the dead the same way as the living. 


\section{References}

CAMPBELL, A., CHARLESWORTH, M., GILLET, G. \& JONES, G. (1997): Medical ethics. Auckland: Oxford University Press.

CLARK, W. R. (1996): Sex \& the origins of death. Oxford: Oxford University Press.

COHEN, C. B. (1983): "Quality of Life" and analogy with the Nazis. In: The Journal of Medicine and Philosophy, 8(5), pp. 113-135.

GLUCHMAN, M. (2013): Medical ethics and the problem of assisted suicide. In: Ethics \& Bioethics (in Central Europe), 3(1-2), pp. 67-75.

GLUCHMAN, M. (2014a): Problém humánnosti a l'udskej dôstojnosti v bioetike [The Problem of Humanity and Human Dignity in Bioethics]. Prešov: Grafotlač.

GLUCHMAN, M. (2014b): The Aspects of Physician Relationship to Patient's Autonomy. In: Ethics \& Bioethics (in Central Europe), 4(1-2), pp. 73-82.

GLUCHMAN, V. (2005): Miesto humánnosti v etike sociálnych dôsledkov [The place of humanity in the ethics of social consequences]. In: Filozofia, 60(8), pp. 613-623.

HERRING, J. (2006): Medical law and ethics (First Edition). Oxford: Oxford University Press.

JENNINGS, B. (2004): Alzheimer's disease and the quality of life. In: K. J. Doka (ed.): Living with Grief: Alzheimer's disease. Washington, D.C.: The Hospice Foundation of America, pp. 197212.

KALAJTZIDIS, J. (2012): Etika sociálnych dôsledkov a hospodárska etika (so zameraním na finančný sektor [Ethics of social consequences and business ethics (with focus on financial sector)]. Brno: Tribun EU.

KALAJTZIDIS, J. (2018): The challenge of death and ethics of social consequences: Death of moral agency. In: Ethics \& Bioethics (in Central Europe), 8(3-4), pp. 209-218.

KLEMBAROVÁ, J. (2015): Etické a morálne aspekty mentálneho postihnutia [Ethical and moral aspects of mental impairment]. Prešov: FF PU.

KOMENSKÁ, K. (2018): Death, ethical judgments and dignity. In: Ethics \& Bioethics (in Central Europe), 8(3-4), pp. 201-208.

LEŠKOVÁ BLAHOVÁ, A. (2010): Bioetika v kontextoch etiky sociálnych dôsledkov (aplikácia zvolenej paradigmy na vybrané bioetické problémy) [Bioethics in the context of ethics of social consequences (Applications of chosen paradigm on selected bioethical issues)]. Prešov: FF PU.

LAURIE, G. (1997): Biotechnology: Facing the problems of Patent Law. In: H. MacQueen \& B. Bain (eds.): Innovation, incentive and reward. Edinburg: Edinburg University Press, pp. 115-131. LIZZA, J. P. (2006): Persons, humanity, and the definition of death. Baltimore: The John Hopkins University Press.

MASON, J. K. (2012): What is in a Name? The Vagaries of Vo v France. In: Child and Family Law Quarterly, 17(1), pp. 97-112.

MCCALL SMITH, A. (1997): Beyond Autonomy. In: Journal of Contemporary Health Law and Policy, 14(23), pp. 5-26.

MCMAHAN, J. (2002): The ethics of killing: Problems at the margins of life. Oxford \& New York: Oxford University Press.

NAGEL, T. (1970): Death. In: Nô̂s, 4(1), pp. 73-80.

NAIR-COLLINS, M. (2017): Can the brain-dead be harmed or wronged? On the moral status of brain death and its implications for organ transplantation. In: Kennedy Institute of Ethics Journal, 27(4), pp. 525-559.

NAIR-COLLINS, M. (2018): A biological theory of death: Characterization, justification, and implications. In: Diametros, 55, pp. 27-43. 
NOWAK, P. G. (2018): Brain death as irreversible loss of a human's moral status. In: Ethics \& Bioethics (in Central Europe), 8(3-4), pp. 167-178.

RANDALL, F. \& DOWNIE, R. S. (2006): The philosophy of palliative care. Oxford: Oxford University Press.

SINGER, P. (1993): Practical Ethics. Cambridge: Cambridge University Press.

SINGER, P. (2018): The challenge of brain death for the sanctity of life ethic. In: Ethics \& Bioethics (in Central Europe), 8(3-4), pp. 153-165.

SHEWMON, D. A. (1998): Chronic ‘Brain Death': Meta-Analysis and Conceptual Consequences. In: Neurology, 51(6), pp. 1538-1545.

SMALL, N., FROGGATT, K. \& DOWNS, M. (2007): Living and dying with dementia: Dialogues about palliative care. Oxford: Oxford University Press.

ŠVANA, L. (2016): ,Etika“ vojny a terorizmu [“Ethics” of war and terrorism]. Bratislava: Veda. VEATCH, R. M. (2015): Killing by organ procurement: Brain-based death and legal fictions. In: Journal of Medicine and Philosophy, 40(3), pp. 289-311.

WOJEWODA, M. (2018): Axiology and the morality of the human being. In: Ethics \& Bioethics (in Central Europe), 8(3-4), pp. 219-226.

ZIEMIŃSKI, I. (2018): The ethical problems of death pronouncement and organ donation: A commentary on Peter Singer's article. In: Ethics \& Bioethics (in Central Europe), 8(3-4), pp. 189200. 